\title{
Ventilatory function in workers exposed to tea and wood dust
}

\author{
Y S AL ZUHAIR, C J WHITAKER, AND F F CINKOTAI \\ From the Department of Occupational Health, University of Manchester, Manchester, UK
}

ABSTRACT Changes in ventilatory capacity during the work shift were studied in workers exposed to tea dust in two tea-packing plants, wood dust in two furniture factories, and virtually no dust in an inoperational power station. The $\mathrm{FEV}_{1}$ and FVC in workers exposed to dust were found to decline during the work shift by a small but significant volume. The MMFR, $\mathrm{V}_{\max } 50 \%$ and $\mathrm{V}_{\max } 75 \%$ were too variable to display any trend. No dose-response relationship could be discerned between the fall in workers' ventilatory capacity and the concentration of airborne dust or microbes to which they were exposed. Bronchodilators could reverse the fall in $\mathrm{FEV}_{1}$.

Many non-allergenic dusts of vegetable or animal origin have been shown to affect acutely the ventilatory capacity of exposed workers. McKerrow et al ${ }^{1}$ found that dust in cotton mills suppressed the "indirect maximum breathing capacity" (IMBC) and increased airway resistance during the working day. These findings were later confirmed ${ }^{2} 3$ and others observed that the $\mathrm{FEV}_{0.75}, \mathrm{FEV}_{1}$, or forced vital capacity (FVC) were similarly affected in workers exposed to flax dusts, ${ }^{45}$ cotton dust, ${ }^{6}$ ? hemp dust, ${ }^{89}$ and jute dust. ${ }^{1011}$ These changes were at one time considered to be byssinotic symptoms even though they occurred also in non-byssinotic subjects. In the past decade, however, workers' $\mathrm{FEV}_{1}$ and FVC in particular were found to decline on exposure to dusts in industries where byssinosis does not occur, such as in coal-mines, ${ }^{12}$ and in wool ${ }^{13}$ and tobacco processing factories. ${ }^{14}$ Similar changes tended to occur in other, occasionally more sensitive but at the same time less reproducible, indices of ventilatory function, such as the maximum midexpiratory flow rate (MMFR), peak-flow (PF), and flow volume curves $\left(\mathrm{V}_{\max } 25 \%, \mathrm{~V}_{\max } 50 \%\right.$, and $V_{\max } 75 \%$ ). Recently, Anderson et al ${ }^{15}$ showed that the FEV 1 fell by a small but significant amount in people who had been rebreathing very high concentrations $\left(2-25 \mathrm{mg} / \mathrm{m}^{3}\right)$ of inert carbon-coated plastic particles for several hours in an exposure chamber.

Evidence suggests that the decline in ventilatory

Received 10 September 1980

Accepted 2 December 1980 capacity that occurs after exposure to some dusts is brought about by airway constriction due to the release of histamine in the bronchioles of the lung. Cotton dust was shown to contain agents that in invitro experiments released about twice as much histamine from lung tissue as other dusts. ${ }^{11} 1617$ Inhalation of an aerosol dispersed from an aqueous extract of cotton bract was found to suppress the $F E V_{1}$ in healthy volunteers and cause a sensation of chest tightness not unlike that felt by byssinotic patients during the first shift of the working week. ${ }^{18}$ Treatment of byssinotic workers with antihistamine drugs was found to block the decline of $F V_{1}$ but significantly did not relieve the feeling of chest tightness and dyspnoea. ${ }^{19}$ The latter symptoms are, according to Rylander, ${ }^{20}$ caused by the invasion of the airways by leucocytes in response to the inhalation of Gram-negative bacteria that usually occur abundantly in the cardrooms of cotton spinning mills. Treatment with antihistamine drugs was found to block the decline of ventilatory capacity also in wool and tobacco workers. ${ }^{13}$

In this study we have investigated the effects of tea and wood dusts on workers exposed to them. A short résumé of part of this study was reported earlier. ${ }^{21}$

\section{Method}

Two tea packing plants (factories 1 and 2), two furniture factories (factories 3 and 4), and a power station (control factory) were investigated. Chests of imported tea were opened in the tea packing plants, blended, and packed into tea bags for retailing. 
Table 1 Mean age, height, weight, and distribution of workers by smoking habit and shift in five factories

\begin{tabular}{|c|c|c|c|c|c|c|c|c|c|c|c|c|c|c|c|}
\hline \multirow[t]{2}{*}{ Department } & \multicolumn{2}{|c|}{$\operatorname{Sex}$} & \multicolumn{2}{|c|}{$\operatorname{Age}(y r)$} & \multirow{2}{*}{$\begin{array}{l}\text { Height }(m) \\
\text { Mean } \pm S D\end{array}$} & \multirow{2}{*}{$\begin{array}{l}\text { Weight }(\text { kg }) \\
\text { Mean } \pm S D\end{array}$} & \multicolumn{3}{|c|}{ Distribution of smoking habit } & \multicolumn{6}{|c|}{ Distribution by shift } \\
\hline & $M$ & $\boldsymbol{F}$ & $\mathrm{Mea}$ & $\min -\max$ & & & $\begin{array}{l}\text { Non- } \\
\text { smokers }\end{array}$ & $\begin{array}{l}\text { Ex- } \\
\text { smokers }\end{array}$ & Smokers & $\begin{array}{l}0600- \\
1400\end{array}$ & $\begin{array}{l}0800- \\
1700\end{array}$ & $\begin{array}{l}1400 \\
2200\end{array}$ & $\begin{array}{l}0730- \\
1230\end{array}$ & $\begin{array}{l}1230 \\
1730\end{array}$ & $\begin{array}{l}170 \\
220\end{array}$ \\
\hline $\begin{array}{l}\text { Blending } \\
\text { Engineering } \\
\text { Packing }\end{array}$ & $\begin{array}{r}32 \\
14 \\
-\end{array}$ & $\frac{-}{21}$ & $\begin{array}{l}30 \cdot 6 \\
36 \cdot 9 \\
32 \cdot 0\end{array}$ & $\begin{array}{l}19-64 \\
20-60 \\
19-57\end{array}$ & $\begin{array}{l}1.72 \pm 0.07 \\
1.70 \pm 0.04 \\
1.61 \pm 0.06\end{array}$ & $\begin{array}{l}\text { Factory } \\
72.53 \pm 10.08 \\
68.05 \pm 5.99 \\
61.3 \pm 7.28\end{array}$ & $\begin{array}{r}1 \\
10 \\
4 \\
10\end{array}$ & $\begin{array}{l}5 \\
2 \\
3\end{array}$ & $\begin{array}{r}17 \\
8 \\
8\end{array}$ & $\begin{array}{r}18 \\
5 \\
-\end{array}$ & $\begin{array}{r}3 \\
1 \\
21\end{array}$ & $\begin{array}{r}11 \\
8 \\
-\end{array}$ & - & - & - \\
\hline $\begin{array}{l}\text { Blending } \\
\text { Machine floor } \\
\text { Packing }\end{array}$ & $\frac{17}{-}$ & $\begin{array}{l}\overline{43} \\
30\end{array}$ & $\begin{array}{l}30 \cdot 0 \\
42 \cdot 1 \\
40 \cdot 5\end{array}$ & $\begin{array}{l}18-45 \\
22-60 \\
21-57\end{array}$ & $\begin{array}{l}1.72 \pm 0.06 \\
1.60 \pm 0.06 \\
1.59 \pm 0.05\end{array}$ & $\begin{array}{l}\text { Factor }) \\
70.01 \pm 10.40 \\
59.48 \pm 7.01 \\
57.90 \pm 9.09\end{array}$ & $\begin{array}{r}2 \\
4 \\
17 \\
11\end{array}$ & $\begin{array}{l}4 \\
8 \\
4\end{array}$ & $\begin{array}{r}9 \\
18 \\
15\end{array}$ & 17 & E & - & $\begin{array}{l}\overline{18} \\
12\end{array}$ & $\begin{array}{l}\overline{13} \\
10\end{array}$ & $\begin{array}{r}12 \\
8\end{array}$ \\
\hline $\begin{array}{l}\text { Saw mill } \\
\text { Assembly }\end{array}$ & $\begin{array}{l}40 \\
13\end{array}$ & - & $\begin{array}{l}33 \cdot 5 \\
32 \cdot 9\end{array}$ & $\begin{array}{l}18-60 \\
20-55\end{array}$ & $\begin{array}{l}1.71 \pm 0.05 \\
1.71 \pm 0.07\end{array}$ & $\begin{array}{l}\text { Factory } \\
74 \cdot 72 \pm 9 \cdot 29 \\
76 \cdot 21 \pm 9 \cdot 11\end{array}$ & $\begin{array}{r}3 \\
13 \\
1\end{array}$ & $\begin{array}{l}7 \\
2\end{array}$ & $\begin{array}{l}20 \\
10\end{array}$ & 18 & $\begin{array}{r}7 \\
13\end{array}$ & 15 & - & - & - \\
\hline $\begin{array}{l}\text { Machine floor } \\
\text { Cabinet shop } \\
\text { Office }\end{array}$ & $\begin{array}{r}23 \\
37 \\
6\end{array}$ & - & $\begin{array}{l}36 \cdot 4 \\
24 \cdot 1 \\
36 \cdot 4\end{array}$ & $\begin{array}{l}18-60 \\
18-61 \\
20-61\end{array}$ & $\begin{array}{l}1.68 \pm 0.07 \\
1.70 \pm 0.07 \\
1.62 \pm 0.09\end{array}$ & $\begin{array}{l}\text { Factory } \\
68 \cdot 79 \pm 10.40 \\
68.49 \pm 11 \cdot 12 \\
62.65 \pm 14.65\end{array}$ & $\begin{array}{r}4 \\
6 \\
15 \\
1\end{array}$ & $\begin{array}{l}9 \\
4 \\
7\end{array}$ & $\begin{array}{r}8 \\
18 \\
3\end{array}$ & - & $\begin{array}{l}23 \\
37 \\
11\end{array}$ & - & - & - & - \\
\hline Power station & 47 & 5 & $41 \cdot 1$ & $18-64$ & $1 \cdot 72 \pm 0.08$ & $\begin{array}{c}\text { Control fa } \\
72.04 \pm 11.72\end{array}$ & $\begin{array}{c}\text { ctory } \\
19\end{array}$ & 20 & 13 & - & 52 & - & - & - & - \\
\hline
\end{tabular}

Factory 1 was an old, dusty plant with a stable and long-standing working population while factory 2 was a brand new plant that was nevertheless dusty because no dust suppression equipment was provided. The third factory specialised in making cabinets and cupboards of veneered chipboard and in factory 4 chairs, tables, and cabinets were produced in the traditional style from a wide range of soft and hard woods such as limba, beech, ash, and, to a lesser extent, from mahogany, oak, and ramin. Saw and machine shops were the dustiest sections in factories 3 and 4 and in addition to wood dust, workers in the finishing sections were exposed to sprays of dye and varnish. The power station was shut down for maintenance at the time of the study, and people working there were minimally exposed to airborne particles.

In all, 333 people aged between 18 and 60 took part in the study: 229 men, 104 women, 147 smokers, 75 ex-smokers, and 111 non-smokers (table 1). The participants engaged in light to medium manual labour and worked several different shifts in various dusty and clean departments.

The FEV , FVC, and MMFR were determined using the Vitalograph. Flow-volume curves were monitored by a Fleisch No 4 pneumotachograph and the McDermott dry spirometer. A pressure transducer and a carrier preamplifier converted the pressure difference across the pneumotachograph (a function of volume flow) into an electrical signal which, together with the signal from the McDermott spirometer, was displayed on the $\mathrm{X}$ and $\mathrm{Y}$ axis of a storage oscilloscope, and the resultant flow volume was photographed. The volume flow was measured at
$50 \%\left(V_{\max } 50 \%\right)$ and $75 \%\left(V_{\max } 75 \%\right)$ of vital capacity. Lung volumes were determined by the Morgan resparameter. The instruments were calibrated by water displacement techniques.

The mass concentrations of airborne dust $\left(\mathrm{mg} / \mathrm{m}^{3}\right)$ in the workers' breathing zone were determined by Casella personal dust samplers (at a flow rate of about $21 / \mathrm{min}$ ) and that in the work zone was measured by the Rotheroe-Mitchell L60 areal dust samplers (at a flow rate of about $601 / \mathrm{min}$ ) at a height of roughly $1.5 \mathrm{~m}$. The glass-fibre filters used were conditioned in a desiccator before weighing them on a Cahn electrical microbalance. The concentration of airborne respirable dust was measured by the Hexhlet (at a flow rate of $501 / \mathrm{min}$ ) and the size distribution (aerodynamic diameter) of airborne particles was estimated by the seven-stage Battelle cascade impactor (at a flow rate of $12 \cdot 5 \mathrm{l} / \mathrm{min}$ ).

The concentration of viable airborne microorganisms $\left(\mathrm{N} / \mathrm{m}^{3}\right)$ in the work zone was measured using the Andersen 2000 Viable Sampler (at a flow rate of $28.3 \mathrm{l} / \mathrm{min}$ ). This is a multijet cascade impactor in which petri-dishes filled with culture media take the place of impactor plates. Samples of organisms were deposited on selective media for growing fungi (5\% malt extract agar), Gram-negative bacteria (endo-agar including penicillin), and Gram-positive bacteria (nutrient agar including nalidixic acid). After a period of suitable incubation (three to seven days at room temperature for the malt extract agar and $24 \mathrm{~h}$ at $37^{\circ} \mathrm{C}$ and a second $24 \mathrm{~h}$ at room temperature for the nutrient and endo-agar media) the colonies of micro-organisms were counted and the counts corrected according to the positive hole 
conversion tables supplied by the manufacturers of the Andersen sampler. Precise identification of the microbe colonies was not attempted.

\section{Procedure}

In a preliminary session each subject was weighed and had his or her height measured, was given the MRC respiratory questionnaire (1971), and was tested for ventilatory capacity by blowing into the Vitalograph and the McDermott spirometer after having first familiarised themselves with the instruments. The $\mathrm{FEV}_{1}, \mathrm{FVC}, \mathrm{MMFR}, \mathrm{V}_{\max } 50 \%$, and $\mathrm{V}_{\max } 75 \%$ were computed from records of the mean of two best blows.

In the main study the ventilatory indices were determined in each subject just before and immediately after a Monday and a Thursday work shift. At the same time the concentration of airborne dust to which the workers were exposed was monitored in some workers' breathing zones by personal dust samplers with which they were fitted for the duration of the shift. The concentration of airborne dust in the work zone, airborne respirable dust, airborne fungi, and bacteria were monitored in one to three strategically selected positions in the zone during the work shift by areal dust and microbe samplers at a height of $1.5 \mathrm{~m}$.

In a separate study 26 workers whose ventilatory capacity had been found to decline during the work shift in one of the two tea packing plants (factory 1) were given bronchodilator drugs to ascertain whether or not the observed changes could be reversed. Isoprenaline sulphate (Iso-autohaler, Rika Labs) was administered at the end of the shift on a Monday and ipratropium bromide (Atrovent, Boehinger) at the same time on another Monday, both in aerosol forms through inhalers in measured doses of $0.16 \mathrm{mg}$ and $2 \times 0.02 \mathrm{mg}$ respectively. Although these drugs are perfectly safe, they were, nevertheless, given under full medical supervision; intravenous lignocaine and emergency resuscitators were available in the unlikely event of cardiac arrhythmia. The blood pressure and heart rate were

Table 2 Concentration of whole and respirable dust in work zones and in workers' breathing zones with mass median aerodynamic diameter of airborne particles and the concentration of airborne microbes in factories 1 to 4

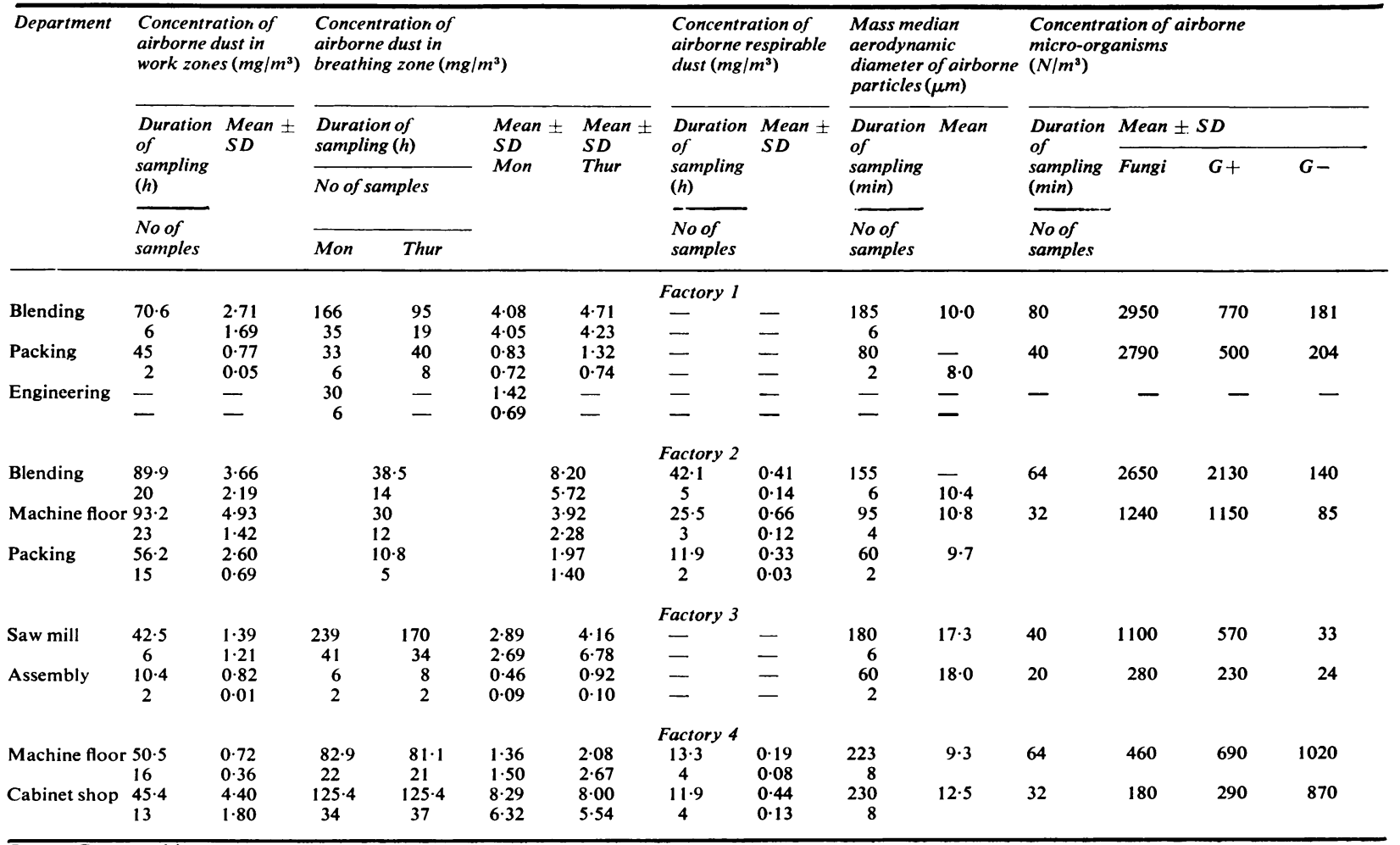


Table 3 Mean and standard deviations of difference between preshift and postshift ventilatory function measurements of asymptomatic packers and machine operators in factory 2

\begin{tabular}{|c|c|c|c|c|c|c|c|c|c|c|c|}
\hline & & \multicolumn{2}{|l|}{$\triangle F E V_{1}$} & \multicolumn{2}{|l|}{$\Delta F V C$} & \multicolumn{2}{|l|}{$\triangle M M F R$} & \multicolumn{2}{|c|}{$\Delta V_{\max } 50 \%$} & \multicolumn{2}{|c|}{$\Delta V_{\max } 75 \%$} \\
\hline & & $\begin{array}{l}\text { Mon } \\
(n=73)\end{array}$ & $\begin{array}{l}\text { Thurs } \\
(n=7 I)\end{array}$ & $\begin{array}{l}\text { Mon } \\
(n=73)\end{array}$ & $\begin{array}{l}\text { Thurs } \\
(n=71)\end{array}$ & $\begin{array}{l}\text { Mon } \\
(n=72)\end{array}$ & $\begin{array}{l}\text { Thurs } \\
(n=70)\end{array}$ & $\begin{array}{l}\text { Mon } \\
(n=71)\end{array}$ & $\begin{array}{l}\text { Thurs } \\
(n=69)\end{array}$ & $\begin{array}{l}\text { Mon } \\
(n=7 I)\end{array}$ & $\begin{array}{l}\text { Thurs } \\
(n=69)\end{array}$ \\
\hline \multirow{4}{*}{$\begin{array}{l}\text { One-way analysis of } \\
\text { effects of } 3 \text { shifts } \\
t \text {-test on significance } \\
\text { of change in } \\
\text { ventilatory function }\end{array}$} & $\begin{array}{l}\text { ariance on } \\
\text { All employees }\end{array}$ & NS & NS & $\mathrm{p}<0.05$ & NS & $\begin{array}{l}\text { NS } \\
0.02\end{array}$ & NS & $\underline{p}<0.01$ & $\begin{array}{l}\mathrm{p}<0.01 \\
-\end{array}$ & $\begin{array}{l}\mathrm{p}<0.01 \\
-\end{array}$ & $\begin{array}{l}\text { NS } \\
-0.01\end{array}$ \\
\hline & $\begin{array}{l}\text { Shift } 1 \\
0730-1230\end{array}$ & \pm 0 & \pm 0 & $\begin{array}{l}-0.006 \\
\pm 0.13 \\
(\mathrm{n}=30)\end{array}$ & \pm & \pm & \pm & $\begin{array}{l}-0 \cdot 12 \\
\pm 0.36 \\
(\mathrm{n}=30)\end{array}$ & $\begin{array}{l}-0.08 \\
\pm 0.32 \\
(\mathrm{n}=30)\end{array}$ & $\begin{array}{l}-0 \cdot 02 \\
\pm 0 \cdot 19 \\
(\mathrm{n}=30)\end{array}$ & $\perp$ \\
\hline & $\begin{array}{l}\text { Shift } 2 \\
1230-1730\end{array}$ & - & - & $\begin{array}{c}0.08^{*} \\
\pm 0.11 \\
(\mathrm{n}=23)\end{array}$ & - & - & - & $\begin{array}{c}0.05 \\
\pm 0.36 \\
(\mathrm{n}=21)\end{array}$ & $\begin{array}{l}-0.05 \\
\pm 0.50 \\
(n=20)\end{array}$ & $\begin{array}{c}0.04 \\
\pm 0.23 \\
(n=21)\end{array}$ & 一 \\
\hline & $\begin{array}{l}\text { Shift } 3 \\
1700-2200\end{array}$ & - & - & $\begin{array}{c}0.08^{*} \\
0.18 \\
(n=20)\end{array}$ & - & - & - & $\begin{array}{c}0 \cdot 19^{*} \\
\pm 0 \cdot 25 \\
(\mathrm{n}=20)\end{array}$ & $\begin{array}{l}0.28 * * \\
\pm 0.32 \\
(\mathrm{n}=19)\end{array}$ & $\begin{array}{c}0 \cdot 17^{* *} \\
\pm 0 \cdot 15 \\
(n=20)\end{array}$ & * - \\
\hline
\end{tabular}

${ }^{*} \mathrm{p}<0.05, * * \mathrm{p}<0.01, * * * \mathrm{p}<0.001$

continually monitored. Indices of ventilatory capacity $\left(F V_{1}, F V C\right.$, MMFR, $V_{\max } 50 \%$ and $V_{\max } 75 \%$ ) were determined before and after the work shift and five to 15 minutes after the administration of the drugs. The concentrations of airborne dust, fungi, and bacteria in the zones where the subjects worked were estimated by areal sampling. The drugs were also given to a group of seven healthy volunteers in this department, and their ventilatory capacity was monitored before and for six hours after their inhalation.

\section{Results}

The concentrations of airborne dust in various work zones in the tea packing plants (factories 1 and 2) and the furniture factories ( 3 and 4 ) were found to vary between 0.77 and $4.40 \mathrm{mg} / \mathrm{m}^{3}$ and the mass median aerodynamic diameter (MMAD) of the airborne particles between 8 and $18 \mu \mathrm{m}$ (table 2). The respirable fraction, where measured by the Hexhlet, formed only a relatively small portion of the total airborne matter (not more than $0.66 \mathrm{mg} / \mathrm{m}^{3}$ ). Airborne dust concentrations in the workers' breathing zone were between 0.46 and $8.3 \mathrm{mg} / \mathrm{m}^{3}$ and tended to be higher than those encountered in the work zones. The cleanest plant was factory 3 where the airborne dust consisted of large non-inhalable particles in relatively low concentrations. The power station was free of internally generated dust as it was inoperative at the time of the study. Airborne viable micro-organisms occurred in all factories in moderate concentrations (table 2). Airborne fungi were more numerous in the tea packing plants; Gram-negative organisms occurred in surprisingly high concentrations in factory 4.

Analysis of covariance showed that there was no relation between changes in ventilatory indices

Table 4 Mean and standard deviations of difference between preshift and postshift ventilatory function measurements in a number of asymptomatic workers

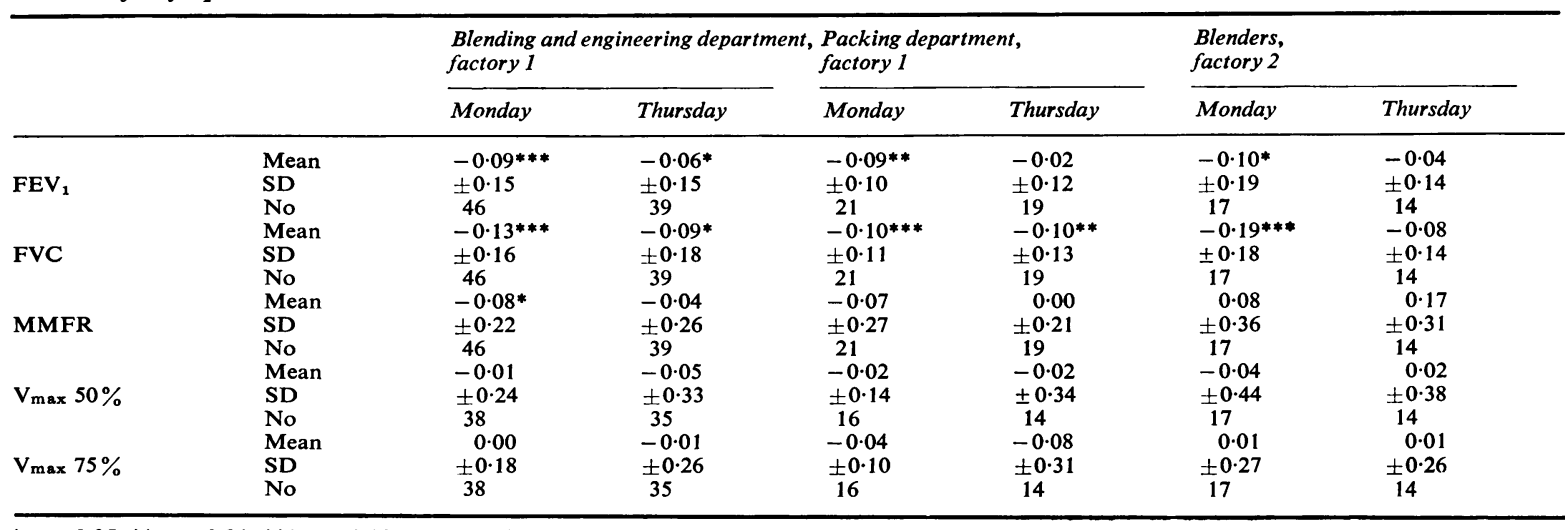

${ }^{*} p<0.05, * * p<0.01, * * * p<0.001,+15$ readings lost due to technical reasons. 
Table 5 Ventilatory indices in 26 tea workers before work shift, after work shift, and after treatment with bronchodilator

\begin{tabular}{|c|c|c|c|c|c|c|c|c|c|c|}
\hline \multirow{2}{*}{$\begin{array}{l}\text { Ventilatory } \\
\text { index }\end{array}$} & \multicolumn{5}{|c|}{ Isoprenaline } & \multicolumn{5}{|l|}{ Atrovent } \\
\hline & $\begin{array}{l}\text { Preshift } \\
\text { Mean } \pm \\
\text { SD }\end{array}$ & $\begin{array}{l}\text { Postshift } \\
\text { Mean } \pm \\
S D\end{array}$ & Change & $\begin{array}{l}\text { After } \\
\text { treatment } \\
\text { Mean } \pm \\
S D\end{array}$ & Change & $\begin{array}{l}\text { Preshift } \\
\text { Mean } \pm \\
S D\end{array}$ & $\begin{array}{l}\text { Postshift } \\
\text { Mean } \pm \\
S D\end{array}$ & Change & $\begin{array}{l}\text { After } \\
\text { treatment } \\
\text { Mean } \pm \\
S D\end{array}$ & Change \\
\hline $\mathrm{FEV}_{1}(\mathrm{l})$ & $\begin{array}{l}3.40 \\
0.94\end{array}$ & $\begin{array}{l}3 \cdot 30 \\
0 \cdot 92\end{array}$ & $-0 \cdot 1 * *$ & $\begin{array}{l}3.41 \\
0.92\end{array}$ & $0 \cdot 11 * * *$ & $\begin{array}{l}3 \cdot 31 \\
0.86\end{array}$ & $\begin{array}{l}3 \cdot 30 \\
0 \cdot 86\end{array}$ & -0.01 & $\begin{array}{l}3.38 \\
0.87\end{array}$ & $0.08 * *$ \\
\hline FVC (I) & $\begin{array}{l}4.45 \\
1.06\end{array}$ & $\begin{array}{l}4 \cdot 32 \\
1 \cdot 09\end{array}$ & $-0 \cdot 13 * * *$ & $\begin{array}{l}4 \cdot 38 \\
1 \cdot 08\end{array}$ & 0.06 & $\begin{array}{l}4.40 \\
1.06\end{array}$ & $\begin{array}{l}4 \cdot 36 \\
1 \cdot 04\end{array}$ & -0.04 & $\begin{array}{l}4.41 \\
1.01\end{array}$ & 0.05 \\
\hline MMFR (1/sec) & $\begin{array}{l}3 \cdot 21 \\
1 \cdot 50\end{array}$ & $\begin{array}{l}3.04 \\
1.47\end{array}$ & $-0 \cdot 17$ & $\begin{array}{l}3 \cdot 33 \\
1 \cdot 58\end{array}$ & $0 \cdot 29 * * *$ & $\begin{array}{l}2.97 \\
1 \cdot 31\end{array}$ & $\begin{array}{l}2 \cdot 93 \\
1 \cdot 34\end{array}$ & -0.04 & $\begin{array}{l}3.09 \\
1.41\end{array}$ & $0 \cdot 16^{* *}$ \\
\hline $\begin{array}{l}V_{\max } 50 \% \\
(1 / \mathrm{sec})\end{array}$ & $\begin{array}{l}3.67 \\
1 \cdot 58\end{array}$ & $\begin{array}{l}3.67 \\
1.70\end{array}$ & 0.00 & $\begin{array}{l}3.92 \\
1.71\end{array}$ & $0 \cdot 25 * * *$ & $\begin{array}{l}3.53 \\
1 \cdot 34\end{array}$ & $\begin{array}{l}3.48 \\
1.42\end{array}$ & -0.05 & $\begin{array}{l}3.68 \\
1.62\end{array}$ & $0 \cdot 20^{*}$ \\
\hline $\begin{array}{l}V_{\max } 75 \% \\
(1 / \mathrm{sec})\end{array}$ & $\begin{array}{l}1.45 \\
0.83\end{array}$ & $\begin{array}{l}1.42 \\
0.89\end{array}$ & -0.03 & $\begin{array}{l}1.57 \\
0.97\end{array}$ & $0 \cdot 15^{* *}$ & $\begin{array}{l}1.44 \\
0.79\end{array}$ & $\begin{array}{l}1 \cdot 36 \\
0 \cdot 79\end{array}$ & -0.08 & $\begin{array}{l}1.43 \\
0.87\end{array}$ & $0.07 *$ \\
\hline
\end{tabular}

$* \mathrm{p}<0.05, *{ }^{*} \mathrm{p}<0.01, * * \mathrm{p}<0.001$. Significance values calculated using paired $t$-test.

during work shift and age or height or weight or smoking habit. The changes in factory 2 , however, did relate to the time of day the work shift took place (morning, afternoon, or evening, table 3). Therefore to test for significance in this factory, a one-way analysis of variance and then a one-sample $t$-test ${ }^{22}$ were performed to ascertain whether or not the differences between ventilatory indices measured before and after work shifts were zero. In factories 1,3 , and 4 these differences were tested simply by using the paired $t$-test.

A statistically significant fall in FEV 1 and FVC of up to 0.191 was found during the work shift in several groups of workers (including office workers) employed in the dusty factories (table 4). Other ventilatory indices monitored, such as the MMFR, $V_{\max } 50 \%$, and $V_{\max } 75 \%$, did not show any trend. Factory 3 was the only plant, apart from the power station, where FEV 1 and FVC did not consistently decrease during the work shift.
Up to 15 minutes after the inhalation of a dose of isoprenaline or atrovent aerosol the ventilatory capacity rose by a small but consistent amount in the group of 26 tea workers (table 5) and in the seven healthy volunteers. ${ }^{23}$ Increases in the FEV ${ }_{1}$, MMFR, and $\mathrm{V}_{\max } 50 \%$ were pronounced, whereas those in the FVC were negligible. Changes in the ventilatory indices were similar in the two groups.

The percentage of subjects with respiratory symptoms did not significantly differ from that in the normal working population. ${ }^{24}$

\section{Discussion}

The changes observed in FEV 1 and FVC in workers exposed to tea or wood dusts during work shifts were comparable in magnitude to those reported in coal miners, wool spinners, and tobacco workers. ${ }^{12-14}$ Changes in other ventilatory indices were evidently too variable to show any trends. No dose-response

\begin{tabular}{|c|c|c|c|c|c|c|c|}
\hline \multicolumn{2}{|c|}{$\begin{array}{l}\text { All worker, } \\
\text { factory } 3\end{array}$} & \multicolumn{2}{|c|}{$\begin{array}{l}\text { Machine and cabinet shops, } \\
\text { factory } 4\end{array}$} & \multicolumn{2}{|c|}{$\begin{array}{l}\text { Office workers, } \\
\text { factory } 4\end{array}$} & \multicolumn{2}{|c|}{$\begin{array}{l}\text { All workers at a power } \\
\text { station }\end{array}$} \\
\hline Monday & Thursday & Monday & Thursday & Monday & Thursday & Monday & Thursday \\
\hline $\begin{array}{c}-0.02 \\
\pm 0.12 \\
53 \\
-0.04 \\
\pm 0.19 \\
53 \\
-0.03+ \\
\pm 0.21 \\
53 \\
-0.03 \\
\pm 0.33 \\
53 \\
-0.06 \\
\pm 0.23 \\
53\end{array}$ & $\begin{array}{c}-0.05 \\
\pm 0.15 \\
53 \\
-0.09 * \\
\pm 0.19 \\
53 \\
-0.10 \dagger \\
\pm 0.29 \\
53 \\
0.03 \\
\pm 0.26 \\
53 \\
-0.04 \\
\pm 0.18 \\
53\end{array}$ & $\begin{array}{l}-0.08 * * * \\
\pm 0 \cdot 14 \\
60 \\
-0 \cdot 12 * * * \\
\pm 0 \cdot 15 \\
60 \\
-0 \cdot 08 \\
\pm 0 \cdot 29 \\
60 \\
0 \cdot 07 \\
\pm 0 \cdot 34 \\
60 \\
0.02 \\
\pm 0 \cdot 22 \\
60\end{array}$ & $\begin{array}{l}-0.11^{* * *} \\
\pm 0.28 \\
58 \\
-0.12 * * * \\
\pm 0.18 \\
58 \\
-0.08 \\
\pm 0.35 \\
58 \\
-0.01 \\
\pm 0.29 \\
58 \\
0.00 \\
\pm 0.24 \\
58\end{array}$ & $\begin{array}{c}0.01 \\
\pm 0.12 \\
11 \\
-0.02 \\
\pm 0.11 \\
11 \\
0.03 \\
\pm 0.35 \\
11 \\
0.06 \\
\pm 0.39 \\
11 \\
0.03 \\
\pm 0.16 \\
11\end{array}$ & $\begin{array}{c}-0.09 * \\
\pm 0.11 \\
11 \\
-0.13^{* *} \\
\pm 0.10 \\
11 \\
-0.06 \\
\pm 0.34 \\
11 \\
-0.07 \\
\pm 0.47 \\
11 \\
0.10 \\
\pm 0.25 \\
11\end{array}$ & $\begin{array}{c}-0.02 \\
\pm 0.15 \\
52 \\
-0.01 \\
\pm 0.21 \\
52 \\
-0.06 \\
\pm 0.36 \\
52 \\
-0.01 \\
\pm 0.35 \\
52 \\
0.01 \\
\pm 0.19 \\
52\end{array}$ & $\begin{array}{c}-0.02 \\
\pm 0.15 \\
52 \\
-0.04 \\
\pm 0.17 \\
52 \\
0.06 \\
\pm 0.28 \\
52 \\
-0.02 \\
\pm 0.31 \\
52 \\
-0.01 \\
\pm 0.21 \\
52\end{array}$ \\
\hline
\end{tabular}


relationship was found in any factory between the levels of exposure to airborne dust or microbes and changes in FEV 1 and FVC, although those exposed to the highest dust concentrations (in factory 4) tended to show the largest drop in $\mathrm{FEV}_{1}$ and FVC (table 3). Those employed in factory 3 and the power station, where dust levels were the lowest, showed no change at all. In factory 4, where airborne Gramnegative bacteria as well as dust occurred in relatively high concentrations, the FEV 1 and FVC tended to decline during working hours, even in office workers whose offices were in the factory building (table 3 ).

In a separate study (to be published) we were, like other researchers, ${ }^{25} 26$ unable to detect a circadian rhythm in the ventilatory indices of a group of 19 healthy individuals monitored four hourly round the clock. Earlier studies that took place in industry, ${ }^{\mathbf{6 1 2} 27}$ however, indicated a significant rise of up to 0.151 in FEV during morning shifts and a similar fall in afternoon and evening shifts. In the present investigation the effects of airborne matter on the ventilatory indices were determined during morning and day shifts in all but 77 subjects who worked on afternoon shifts. Thus the observed decline in FEV 1 and FVC is in sharp contrast with a rise that might have been expected according to a circadian rhythm.

The administration of bronchodilators, especially of isoprenaline, to a group of 26 people employed in one of the tea placking plants reversed the decrease in all ventilatory indices but the FVC at the end of a Monday shift (table 5). The administration of these aerosols increased the ventilatory capacity also in seven healthy staff members of this department with much of the effect developing within minutes after treatment. As observed before ${ }^{28} 29$ the greatest improvements were obtained in the MMFR and maximum expiratory flow rates (particularly in $V_{\max } 50 \%$ ) rather than the FEV 1 . Therefore, the decrease of ventilatory capacity in the workers exposed to dust during the work shift was probably due to bronchoconstriction.

Cotton dust that has been shown to include some histamine-releasing agents depresses the ventilatory capacity in many workers during a work shift considerably more than wool, tobacco, tea, or wood dusts, which presumably contain histaminereleasing agents in lower concentrations. Dusts consisting of inert coal or plastic particles may release histamine by mechanical irritation when they deposit in the pulmonary tract. The resultant bronchoconstriction may be a physiological rather than a pathological reaction to dust exposure. The narrowing of airways enhances airflow turbulence, which in turn increases the rate of particle deposition into the tracheobronchial region from where deposited particles are cleared out efficiently by the ciliary mechanism. Thus bronchoconstriction tends to prevent the entry of respirable particles into the alveolar region, which is considerably more vulnerable to the toxic effects of foreign bodies than the tracheobronchial region.

This study was partially financed by a Medical Research Council grant. We are grateful to the workers, management, and trade union representatives of the factories for their whole-hearted support of this project.

\section{References}

1 McKerrow CB, McDermott M, Gilson JC, Schilling RSF. Respiratory function during the day in cotton workers: a study in byssinosis. Br J Ind Med 1958;15:75-83.

${ }^{2}$ Gilson JC, Stott H, Hopwood BEC, Roach SA, McKerrow CB, Schilling RSF. Byssinosis: the acute effect on ventilation capacity of dusts in cotton ginneries, and cotton, sisal, and jute mills. Br J Ind Med 1962;19:9-18.

${ }^{3}$ El Batawi MA, Schilling RSF, Valic F, Walford J. Byssinosis in the Egyptian cotton industry: changes in ventilatory capacity during the day. $\mathrm{Br} J$ Ind Med 1964; $21: 13-9$.

4 Mair A, Smith DH, Wilson WA, Lockhart W. Dust disease in Dundee textile workers: an investigation into chronic respiratory disease in jute and flax industries. Br J Ind Med 1960;17:272-8.

${ }^{5}$ Bouhuys A, van Duyn J, van Lennep HJ. Byssinosis in flax workers. Arch Environ Health 1961;3:499-509.

${ }^{6}$ Walford J, Lammers B, Schilling RSF, van den-Hoven van Genderen D, van der Veen YG. Diurnal variation in ventilatory capacity. An epidemiological study of cotton and other factory workers employed on shift work. $\mathrm{Br} J$ Ind Med 1966;23:142-8.

${ }^{7}$ Berry G, McKerrow CB, Molyneux M, Rossiter CB, Tombleson JB. A study of the acute and chronic changes in ventilatory capacity of workers in Lancashire cotton mills. Br J Ind Med 1973;30:25-36.

${ }^{8}$ Bouhuys A, Babero A, Lindell SE, Roach SA, Schilling RSF. Byssinosis in hemp workers. Arch Environ Health 1967; 14:533-44.

9 Valic F, Zuskin E, Walford J, Kersic W, Paukovic R. Byssinosis, chronic bronchitis, and ventilatory capacities in workers exposed to soft hemp dust. $\mathrm{Br} J$ Ind Med 1968;25:176-86.

${ }^{10}$ Gandevia B, Milne J. Ventilatory capacity on exposure to jute dust and the relevance of productive cough and smoking to the response. $\mathrm{Br} J$ Ind Med 1965;22:187-95.

${ }^{11}$ Valic F, Zuskin E. A comparative study of respiratory function in female non-smoking cotton and jute workers. Br J Ind Med 1971 ;28:364-8.

12 Lapp NL, Hankinson JL, Burgess DB, O'Brien R. Changes in ventilatory function in coal miners after a workshift. Arch Environ Health 1972;24:204-8.

${ }^{13}$ Zuskin E, Valic F, Bouhuys A. Effect of wool dust on respiratory function. Am Rev Respir Dis 1976;114:705-9.

14 Valic F, Beritic D, Butkovic D. Respiratory response to tobacco dust exposure. Am Rev Respir Dis 1976;113: 751-5.

${ }^{15}$ Andersen IB, Lundquisit GR, Proctor DF, Swift DL. Human response to controlled levels of inert dust. Am Rev Respir Dis 1979;119:619-27.

${ }^{16}$ Bouhuys A, Lindell SE, Lundin G. Experimental studies on byssinosis. Br Med J 1960;i:329-36. 
${ }^{17}$ Bouhuys A, Lindell SE. Release of histamine by cotton dust extracts from human lung tissue in vitro. Experimentia 1961;17:211-5.

${ }^{18}$ Bouhuys A, Nichols PJ. The effect of cotton dust on respiratory mechanics in men and guinea pigs. In: Davies CN (ed). Inhaled particles and vapours. Vol 2. New York: Pergamon Press, 1967:75-85.

19 Bouhuys A. Prevention of Monday dyspnoea in byssinosis -a controlled trial with antihistamine. Clin Pharmacol Ther 1963;4:311-4.

${ }^{20}$ Rylander R. Exposure to Gram-negative bacteria and the development of byssinosis. XIX International Conference on Occupational Health, Dubrovnik, Yugoslavia. Zagreb: Institute of Medical Research and Occupational Health, 1978;272. (Abstracts.)

21 Al-Zuhair YS, Cinkotai FF. Ventilatory function in workers exposed to tea and wood dust. IRCS Journal of Medical Science 1977;5:190.

${ }^{22} \mathrm{Nie}$ NH, Hull CH, Jenkins JG, Steinbrenner K, Bent DH. Statistical package for the social sciences. London: McGraw-Hill, 1975.

${ }^{23}$ Al Zuhair YS. Short-and some long-term effects of wood and tea dusts on pulmonary function of exposed workers.
University of Manchester, 1980. PhD thesis.

${ }^{24}$ Chinn DJ. The evaluation of the maximal expiratory flow volume curve and the closing volume test; their normal values and relative merits in the early diagnosis of chronic obstructive pulmonary disease. University of Manchester, 1976. PhD thesis.

${ }^{25} \mathrm{Kerr}$ HD. Diurnal variation of respiratory function independent of air quality. Arch Environ Health 1973; 26:144-52.

${ }^{26}$ Cochrane GM, Prieto F, Clark TFH. Intrasubject variabilities of maximum expiratory flow volume curve. Thorax $1977 ; 32: 171-6$.

27 Guberan E, Williams MK, Walford F, Smith MM. Circadian variation in $\mathrm{FEV}_{1}$ in shift workers. $\mathrm{Br} J$ Ind Med 1969;26:121-5.

${ }^{28}$ McFadden ER Jr, Newton-Howes J, Pride NB. Acute effects of inhaled isoproterenol on the mechanical characteristics of the lungs in normal man. $J$ Clin Invest 1970;49:779-90.

${ }^{29}$ Sobol BJ, Emirgil C, Waldie JR, Reed A. The response to isoproterenol in normal subjects and in subjects with asthma. Am Rev Respir Dis 1974;109:290-2.

\section{Vancouver style}

All manuscripts submitted to the $\mathrm{Br} J$ Ind Med should conform to the uniform requirements for manuscripts submitted to biomedical journals (known as the Vancouver style).

The $B r J$ Ind Med, together with many other international biomedical journals, has agreed to accept articles prepared in accordance with the Vancouver style. The style (described in full in $\mathrm{Br}$ Med J, 24 February 1979, p 532) is intended to standardise requirements for authors.

References should be numbered consecutively in the order in which they are first mentioned in the text by Arabic numerals above the line on each occasion the reference is cited (Manson ${ }^{1}$ confirmed other reports ${ }^{2-5} \ldots$. ). In future references to papers submitted to the $\mathrm{Br} J$ Ind $\mathrm{Med}$ should include: the names of all authors if there are six or less or, if there are more, the first three followed by et al; the title of journal articles or book chapters; the titles of journals abbreviated according to the style of Index Medicus; and the first and final page numbers of the article or chapter.

Examples of common forms of references are:

${ }^{1}$ International Steering Committee of Medical Editors. Uniform requirements for manuscripts submitted to biomedical journals. Br Med J 1979;1 :532-5.

${ }^{2}$ Soter NA, Wasserman SI, Austen KF. Cold urticaria: release into the circulation of histamine and eosinophil chemotactic factor of anaphylaxis during cold challenge. $N$ Engl J Med 1976;294:687-90.

${ }^{3}$ Weinstein L, Swartz MN. Pathogenic properties of invading micro-organisms. In: Sodeman WA Jr, Sodeman WA, eds. Pathologic physiology: mechanisms of disease. Philadelphia: W B Saunders, 1974:457-72. 